\section{Harmonisation of laboratory tests for rheumatic diseases: still a long way to go}

Antinuclear antibodies (ANAs), antineutrophil cytoplasmic antibodies (ANCAs), rheumatoid factor (RF) and antibodies to citrullinated peptides (ACPA) are widely used laboratory markers to support the diagnosis of ANA-associated systemic rheumatic diseases, ANCA-associated vasculitis and rheumatoid arthritis. Despite the fact that these tests are broadly used, they all suffer from a lack of harmonisation.

Pisetsky $\mathrm{et} \mathrm{al}^{1}$ recently reported on assay variation in the detection of ANAs in the sera of patients with established systemic lupus erythematosus. Differences in ANA reactivity were found between different indirect immunofluorescence (IIF) methods and between IIF and immunoassays. Infantino et $a l^{2}$ further stressed (1) that such variation holds for fluorescence intensity and for pattern recognition, and (2) that there is no consensus on the IIF cut-off and on whether anticytoplasmic antibodies should be considered ANA. Variation in ANA detection by IIF holds for manual methods and for automated or computer-assisted diagnostic systems. ${ }^{34}$ Largely, there is increasing awareness that there is variation in ANA detection by IIF and that such variation may affect diagnostic/clinical evaluation, entry in clinical trials or prescription of therapeutic agents. ${ }^{5}$ Variation in ANA detection is not limited to IIF but has also been reported in the detection of antigen-specific antibodies by dot/line blot assays. ${ }^{6}$

ANCA detection by IIF also suffers from variation. ${ }^{7-9}$ As variation was less pronounced for proteinase-3 (PR3)-ANCA and myeloperoxidase (MPO)-ANCA by immunoassay, a revised 2017 international consensus on testing of ANCAs in granulomatosis with polyangiitis (GPA) and microscopic polyangiitis (MPA) proposed that high-quality immunoassays can be used as the primary screening method for patients suspected of having the ANCA-associated vasculitides GPA and MPA without the categorical need for IIF. ${ }^{10}$ Even though the overall performance of immunoassays for PR3-ANCA and MPO-ANCA is comparable (similar areas under the receiver operating characteristic curve), ${ }^{11}$ the assays do not give comparable ANCA values. ${ }^{12}$ The use of a reference material could improve comparability of test results for assays that correlate well, which, however, is not the case for all assays. ${ }^{12}$

Finally, poor harmonisation of RF and ACPA assays and of test result interpretation has recently also been reported. ${ }^{13} 14$ For RF there is poor numerical agreement between the assays even though a common reference material is used. ${ }^{13}$ Moreover, manufacturer-specific cut-off values are not aligned between the different assays, resulting in variation in sensitivity and specificity between the assays. ${ }^{13}$ Such variation has clinical consequences as a fraction of patients will or will not be classified as RA (according to the 2010 American College of Rheumatology/European League Against Rheumatism criteria) depending on the assay used.

Taken together, there is variation in most of the assays that are currently widely used to support the diagnosis of rheumatic disorders. Such variation is not limited to IIF but is also observed with other technologies. Laboratory professionals, clinicians and the diagnostic industry should closely collaborate in order to better harmonise the laboratory diagnostic process. ${ }^{15} 16$

Lieve Van Hoovels, ${ }^{1}$ Xavier Bossuyt ${ }^{2}$
'Department of Laboratory Medicine, OLV Hospital, Aalst, Belgium

${ }^{2}$ Department of Laboratory Medicine, University Hospital Gasthuisberg, Leuven, Belgium

Correspondence to Lieve Van Hoovels, Department of Laboratory Medicine, OLV Hospital, Aalst 9300, Belgium; Lieve.Van.Hoovels@olvz-aalst.be

Handling editor Josef S Smolen

Competing interests None declared.

Patient consent Not required.

Provenance and peer review Commissioned; internally peer reviewed.

(C) Author(s) (or their employer(s)) 2020. No commercial re-use. See rights and permissions. Published by BMJ.

\section{(A) Check for updates}

To cite Van Hoovels L, Bossuyt X. Ann Rheum Dis 2020;79:e5.

Received 14 November 2018

Accepted 16 November 2018

Published Online First 4 December 2018

\section{SPlinked}

- http://dx.doi.org/10.1136/annrheumdis-2018-214650

Ann Rheum Dis 2020;79:e5. doi:10.1136/annrheumdis-2018-214696

\section{REFERENCES}

1 Pisetsky DS, Spencer DM, Lipsky PE, et al. Assay variation in the detection of antinuclear antibodies in the sera of patients with established SLE. Ann Rheum Dis 2018;77:911-3.

2 Infantino M, Manfredi M, Soda P, et al. ANA testing in 'real life'. Ann Rheum Dis 2020;79:e3.

3 Van Hoovels L, Schouwers S, Van den Bremt S, et al. Variation in antinuclear antibody detection by automated indirect immunofluorescence analysis. Ann Rheum Dis 2019;78:e48.

4 Mahler M. Lack of standardisation of ANA and implications for drug development and precision medicine. Ann Rheum Dis 2019;78:e33.

5 Pisetsky DS, Spencer DM, Lipsky PE, et al. Response to: 'Variation in antinuclear antibody detection by automated indirect immunofluorescence analysis' by van Hoovels et al. Ann Rheum Dis 2019;78:e49.

6 Vulsteke JB, De Langhe E, Claeys KG, et al. Detection of myositis-specific antibodies. Ann Rheum Dis 2019;78:e7.

7 Csernok E, Damoiseaux J, Rasmussen N, et al. Evaluation of automated multiparametric indirect immunofluorescence assays to detect anti-neutrophil cytoplasmic antibodies (ANCA) in granulomatosis with polyangiitis (GPA) and microscopic polyangiitis (MPA). Autoimmun Rev 2016;15:736-41.

8 Broeders S, Goletti S, Tomasi JP, et al. Revised 2017 international consensus on ANCA testing in small vessel vasculitis: support from an external quality assessment. Ann Rheum Dis 2019;78:e113.

9 Damoiseaux J, Csernok E, Rasmussen N, et al. Detection of antineutrophil cytoplasmic antibodies (ANCAs): a multicentre European Vasculitis Study Group (EUVAS) evaluation of the value of indirect immunofluorescence (IIF) versus antigen-specific immunoassays. Ann Rheum Dis 2017;76:647-53.

10 Bossuyt X, Cohen Tervaert JW, Arimura Y, et al. Position paper: Revised 2017 international consensus on testing of ANCAs in granulomatosis with polyangiitis and microscopic polyangiitis. Nat Rev Rheumatol 2017;13:683-92.

11 Damoiseaux J, Bossuyt X. Clinical relevance of ANCA in small-vessel vasculitis: positioning of antigen-specific immunoassays. Clin Rheumatol 2018;37:2015-6.

12 Rasmussen N, Damoiseaux J, Csernok E, et al. Individual values of antineutrophil cytoplasmic antibodies do not correspond between antigen-specific assays. Clin Chem Lab Med 2018;56:e39-e42.

13 Van Hoovels L, Jacobs J, Vander Cruyssen B, et al. Performance characteristics of rheumatoid factor and anti-cyclic citrullinated peptide antibody assays may impact ACR/EULAR classification of rheumatoid arthritis. Ann Rheum Dis 2018;77:667-77.

14 Falkenburg WJJ, von Richthofen HJ, Koers J, et al. Clinically relevant discrepancies between different rheumatoid factor assays. Clin Chem Lab Med 2018:56:1749-58.

15 Bossuyt X, Louche C, Wiik A. Standardisation in clinical laboratory medicine: an ethical reflection. Ann Rheum Dis 2008:67:1061-3.

16 Jacobs JFM, Bossuyt X. Standardization and harmonization of autoimmune diagnostics. Clin Chem Lab Med 2018;56:1563-7. 